\title{
PENINGKATAN KETERAMPILAN MENULIS NASKAH DRAMA DENGAN MENGGUNAKAN MEDIA LINE WEBTOON PADA SISWA KELAS VIII SMP NEGERI 1 KOTA BENGKULU
}

\author{
Silpani Oktarina, Susetyo, dan Gumono \\ Program Studi Pendidikan Bahasa Indonesia \\ Jurusan Pendidikan Bahasa dan Seni \\ FKIP Universitas Bengkulu \\ osilpani@gmail.com
}

\begin{abstract}
Abstrak
Tujuan penelitian ini untuk mendeskripsikan tentang peningkatan keterampilan menulis naskah drama pada siswa kelas VIII SMP Negeri 1 Kota Bengkulu menggunakan media line webtoon. Penelitian ini merupakan penelitian tindakan kelas dengan model Kemmis dan Mc.Taggart. Subjek dalam penelitian adalah siswa kelas VIII-7 SMP Negeri 1 Kota Bengkulu yang berjumlah 35 orang dan dilaksanakan dalam dua siklus. Hasil penelitian pada siklus I diperoleh nilai rata-rata sebesar 70,1 dengan ketuntasan belajar secara klasikal 25,71\%. Perolehan hasil menulis naskah drama siswa rata-rata masih rendah pada kriteria penilaian dialog, alur dan petunjuk teknis pada siklus I. Pada siklus II diperoleh nilai rata-rata sebesar 83,3 dengan ketuntasan belajar secara klasikal sebesar $80 \%$. Kesulitan siswa dalam menulis naskah drama pada siklus sebelumnya dapat teratasi dengan baik pada siklus II dengan meningkatnya kenaikan skor sebesar 13,2 dan ketuntasan belajar klasikal sebesar 54,12\%. Penggunaan media line webtoon dapat menarik minat siswa dalam pembelajaran menulis naskah drama dan meningkatkan hasil penulisan naskah drama yang telah dilakukan selama 2 siklus.
\end{abstract}

Kata kunci: keterampilan menulis, naskah drama, line webtoon.

\begin{abstract}
The purpose of this study was to describe the improvement of drama script writing skill for eighth grade students of SMP Negeri 1 Kota Bengkulu using the line webtoon media. This study was a classroom action research with the Kemmis and Mc.Taggartmodels. Subjects in the study were class VIII-7 students of SMP Negeri 1 Kota Bengkulu, amount 35 students and carried out in two cycles. The results of the research in cycle I obtained an average value of 70.1 with classical learning completeness $25.71 \%$. The average score of the writing drama script was still low on the criteria for the assessment of dialogue, flow and technical instructions in cycle I. In the second cycle, the average score was 83.3 with the classical learning completeness of $80 \%$. The students difficulty in writing drama script in the previous cycle can be resolved well in cycle II with increasing score increase of 13.2 and classical learning completeness of 54.12\%.By using the media line webtoon can attract the interest of students in learning to write the script of the drama and the drama script writing improve your results from cycle I to cycle II.The use of the line webtoon media can attract the interest of students in writing drama script and increase the result of drama script writing that have been performed in 2 cycles.
\end{abstract}

Keywords: writing skill, drama script, line webtoon. 


\section{PENDAHULUAN}

Menulis merupakan salah satu keterampilan berbahasa diantara tiga keterampilan berbahasa lainnya, yakni keterampilan menyimak, keterampilan berbicara, dan keterampilan membaca. Keempat keterampilan ini terdapat dalam pembelajaran bahasa Indonesia di sekolah. Keterampilan menulis terdiri dari berbagai jenis tulisan, baik keterampilan menulis sastra maupun menulis kebahasaan. Salah satu jenis keterampilan menulis tesebut sesuai dengan kompetensi dasar pada silabus mata pelajaran bahasa Indonesia semester dua kelas VIII SMP/MTs kurikulum 2013, yakni peserta didik harus mampu menyajikan drama dalam bentuk pentas atau naskah. Indikator pencapaian pada penelitian ini, yaitu menulis naskah drama.

Sebagai bagian dari pengajaran sastra di sekolah, drama bertujuan untuk mewujudkan apresasi drama. Ismawati (2013:87) mengemukakan apresiasi drama ditandai dengan sikap dan nilai apresiasi yang dibina di bangku sekolah, proses ini dapat dibagi dalam beberapa tingkatan, yakni tingkat menggemari, tingkat menikmati, tingkat mereaksi, dan tingkat mereproduksi. Menulis naskah drama temasuk pada tingkat mereproduksi, yang ditandai dengan sikap mulai ikut menghasilkan cipta sastra, baik secara profesional maupun amatiran.

Dalam menulis naskah drama tentu bukanlah hal yang mudah, terlebih penulis naskah merupakan peserta didik yang duduk di bangku Sekolah Menengah Pertama. Sukino (2010:6) menyatakan bahwa kesukaran dalam menulis disebabkan mengkomunikasikan ide dengan bahasa tulis tidak semudah mengkomunikasikan ide dengan bahasa lisan. Selain itu, kesulitan yang ada ialah sukar menemukan ide atau bingung harus memulai tulisan dari mana kalaupun sudah menemukan ide atau memulai tulisan, tidak jarang mengalami pemberhentian di tengah jalan. Hasilnya tulisan menggantung atau tidak tuntas. Oleh sebab itu, pemilihan media pembelajaran diperlukan untuk membantu proses kreatif peserta didik tersebut untuk mengembangkan ide ceritanya.

Penulis sudah melakukan wawancara dengan salah seorang guru bahasa Indonesia yang mengajar pada kelas VIII SMP Negeri 1 Kota Bengkulu. Berdasarkan wawancara tersebut, beliau mengungkapkan bahwa peserta didik ketika menulis naskah drama terhambat pada ide cerita yang ingin mereka tuliskan. Materi yang disampaikan bersumber pada buku yang ada di perpustakaan atau buku pegangan guru. Untuk itu, penelitian ini berkaitan dengan kondisi di lapangan dan berharap dengan adanya media komik di era digital ini dapat membantu peserta didik dalam mengembangkan ide cerita, sehingga dapat meningkatkan hasil belajar peserta didik dalam menulis naskah drama. SMP Negeri 1 Kota Bengkulu juga tidak membatasi peserta didik untuk membawa gadget selama itu berguna untuk proses pelaksanaan kegiatan pembelajaran.

Penulis tertarik menggunakan media line webtoon pada materi menulis naskah drama untuk mengembangkan ide cerita peserta didik sesuai dengan fenomena dan perkembangan teknologi saat ini. Penulis memilih line webtoon karena memiliki berbagai genre komik yang dapat dibaca secara online atau offline. Peserta didik bisa menggunakan mobile (iOS dan android) untuk mengunduh line webtoon di play store atau membuka lamannya di web (www.webtoons.com/id), dan memilih komik yang sudah ditentukan oleh guru. Namun peserta didik tidak harus menulis sama persis seperti gambar yang ada di komik tersebut. Peserta didik bisa menambahkan atau bahkan memberikan imajinasi lain yang sesuai dengan ide cerita yang dikembangan oleh peserta didik. 
Menurut Scout McCloud (dalam Waluyanto, 2005:51) memberikan pendapat bahwa komik dapat memiliki arti gambar-gambar serta lambang lain dalam urutan tertentu, untuk menyampaikan informasi dan mencapai tanggapan estetis dari pembacanya. Sudjana dan Rivai (2002:68) menyatakan media komik dalam proses belajar mengajar meciptakan minat para peserta didik, mengefektifkan proses belajar mengajar, dapat meningkatkan minat belajar dan menimbulkan minat apresiasinya. Menurut Hamalik (dalam Arsyad, 2006:5) pemakaian media pembelajaran dalam proses belajar mengajar dapat membangkitkan keinginan dan minat baru, membangkitkan motivasi dan rangsangan kegiatan belajar dan bahkan membawa pengaruh-pengaruh psikologis terhadap siswa.

Pemilihan komik yang ditentukan oleh guru untuk menghindari dampak negatif yang ditimbulkan karena line webtoon juga memiliki berbagai genre komik bagi pembaca dewasa yang tidak layak dibaca oleh anak-anak remaja. Menurut Ratna (2014:413), secara psikologis peserta didik adalah insan yang sedang berada dalam proses pertumbuhan, proses pencarian, selalu ingin mengetahui, dan makhluk bertanya. Peserta didik pada tingkat SMP masih dikategorikan sebagai fase suka meniru. Oleh sebab itu, di samping pendekatan secara klasikal, maka pendekatan secara personal tetap harus dilakukan untuk membangkitkan hubungan kekeluargaan baik guru maupun peserta didik, agar memiliki sikap tanggung jawab ketika proses pembelajaran dilaksanakan.

SMP Negeri 1 Kota Bengkulu juga memiliki fasilitas WiFi guna mempermudah peserta didik untuk mengakses line webtoon yang tersedia di web dan mobile (iOS dan android). Dengan adanya penggunaan media yang sesuai dengan kemajuan teknologi yang semakin berkembang dan fasilitas yang memadai, membuat peserta didik serta guru memanfaatkan semaksimal mungkin, dan tidak hanya berpatokan pada contoh teks drama saja atau buku paket untuk materi naskah drama. Berkaitan dengan penggunaan media yang tepat sebagai upaya meningkatkan keterampilan menulis naskah drama pada peserta didik, penulis melakukan penelitian dengan menggunakan desain Penelitian Tindakan Kelas (PTK) untuk mengetahui peningkatan keterampilan menulis naskah drama dengan menggunakan media line webtoon pada peserta didik kelas VIII SMP Negeri 1 Kota Bengkulu.

\section{METODE}

Metode penelitian yang digunakan merupakan Penelitian Tindakan Kelas (PTK) atau dalam bahasa Inggris disebut Classroom Action Research (CAR). Dalam pembelajaran bahasa dan sastra Indonesia, PTK merupakan suatu kajian mengintrospeksi, mencermin, merefleksi atau mengevaluasi pembelajaran bahasa dan sastra Indonesia yang dilakukan secara terarah, sistematis, terencana, cermat, dan bertanggung jawab guna perbaikan pembelajaran yang pada akhirnya dapat meningkatkan hasil belajar peserta didik dan mutu pembelajaran bahasa dan sastra Indonesia (Susetyo, 2015:89).

Desain PTK pada penelitian ini menggunakan model yang dikembangkan oleh Kemmis dan Mc.Taggart. Terdapat empat aspek komponen penelitian tindakan menurut Kemmis dan Mc.Taggart, yaitu perencanaan, tindakan, observasi, dan refleksi (Susetyo, 2015:97).Jumlah siklus dalam satu penelitian tergantung pada kebutuhan. Siklus pertama bisa diulangi menjadi siklus kedua, yang kemudian diulangi lagi menjadi siklus ketiga dan selanjutnya hingga peneliti menganggap hasil yang ada sudah memuaskan dan saatnya untuk menghentikan penelitian. Pelaksanaan peneliitian dilakukan di kelas 
VIII-7 SMP Negeri 1 Kota Bengkulu dengan subjek penelitian berjumlah 35 orang

Teknik pegumpulan data yang dilakukan pada penelitian ini melalui kegiatan observasi, wawancara, dan dokumentasi. Teknik analisis data pada penelitian disesuaikan dengan teknik tes yang dilakukan tehadap siswa, yakni data menulis naskah drama siswa dengan menggunakan media line webtoon yang meliputi penilaian terhadap aspek dialog, alur atau plot, penokohan dan perwatakan, tema, setting, amanat, dan pentunjuk teknis. Hasil data dianalisis mengikuti skor penilaiankriteria penilaian, kategori penilaian dan analisis kriteria keberhasilan belajar siswa yang telah ditetapkan.

\section{HASIL DAN PEMBAHASAN}

Hasil Penelitian

Perolehan hasil menulis naskah drama siswa siklus I rata-rata masih rendah pada bagian dialog, alur dan masih ada yang salah dalam menulis petunjuk teknis dan hasil meningkat pada siklus II.

Berdasarkan hasi tes pada siklus II, keterampilan menulis naskah drama mengalami peningkatan dari nilai rata-rata dari siklus 1. Pada siklus I diperoleh nilai rata-rata 70,1 sedangkan pada siklus ke II nilai rata-rata siswa meningkat menjadi 83,3 . Berdasarkan hasil tersebut, maka dapat dikatakan bahwa nilai siswa sudah tuntas dan sudah mencukupi KKM sebesar 80. Kesulitan-kesulitan siswa dalam menulis naskah drama dapat teratasi dengan baik karena stuasi pembelajaran siklus II lebih terkondisi. Demikian pembelajaran menulis naskah drama dengan menggunakan line webtoon pada siklus 2 ini telah berhasil meningkatkan keterampilan menulis naskah drama siswa sehingga tidak perlu dilakukan siklusberikutnya.

Hasil analisis data berdasarkan siklus I yang diikuti oleh 35 siswa, didapat nilai rata-rata sebesar 70,1. Jumlah siswa yang tuntas dengan KKM $\leq 80$ sebanyak 9 siswa, sedangkan yang belum tuntas sebanyak 26 siswa, hal ini menunjukkan bahwa siklus I belum memenuhi kriteria keberhasilan. Sedangkan hasil analisis data siklus II didapat nilai rata-rata sebesar 83,3. Jumlah siswa yang tuntas dengan KKM $\leq 80$ sebanyak 27 siswa, sedangkan belum tuntas sebanyak 9 siswa. Hasil rata-rata siswa meningkat 13,2.

\section{Diagram 1. Peningkatan nilai Rata-rata} Siswa

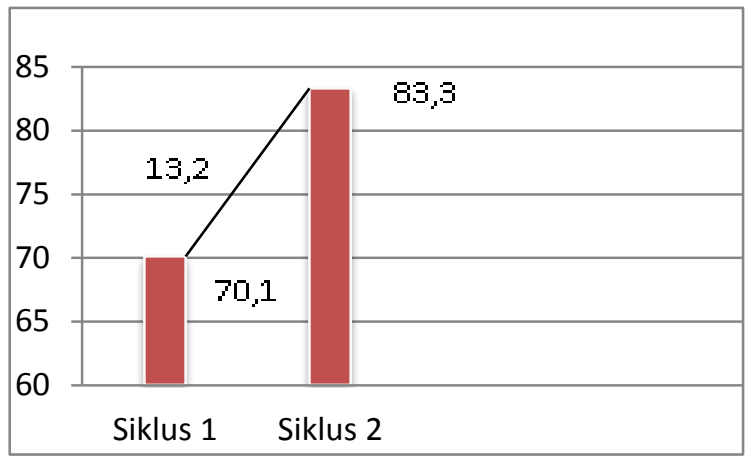

Berdasarkan perolehan penilaian pada siklus I dan siklus II tersebut, terdapat peningkatan yang terjadi di setiap aspek penilaian naskah drama yang berpengaruh pada hasil kentuntasan belajar siswa.

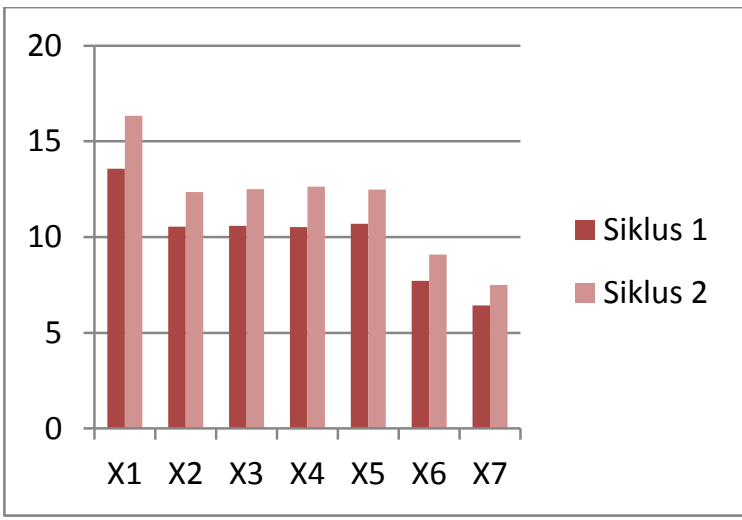

Diagram 2. Perbandingan Hasil Skor Rata-Rata Aspek dalam Menulis Naskah Drama pada Siklus I dan Siklus II

Keterangan:

- X1 : dialog

- X2 : alur atau plot 
- X3 : penokohan dan perwatakan

- X4 : tema

- X4 : settting

- X6 : amanat

- X7 : petunjuk teknis

Berikut ketuntasan belajar klasikal siswa kelas VIII-7 SMP Negeri 1 Kota Bengkulu.

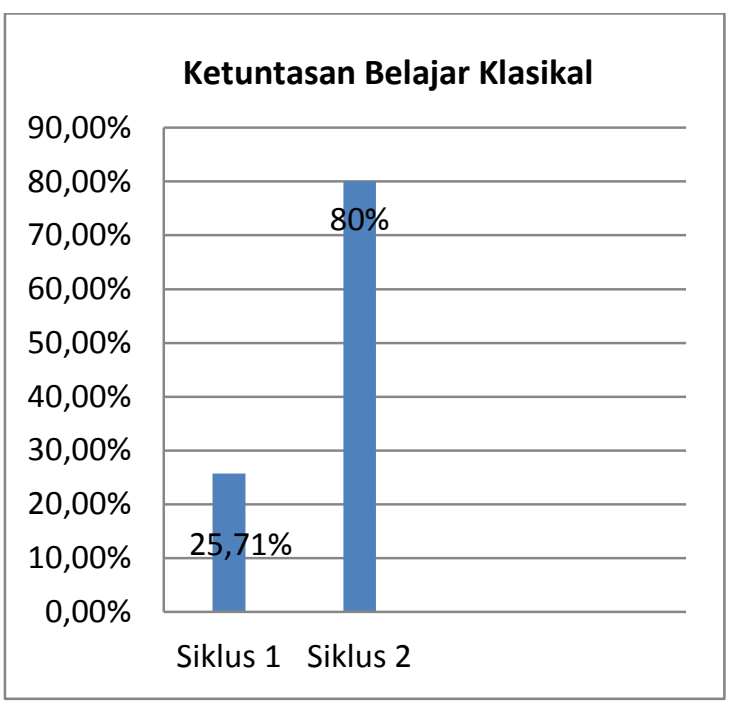

\section{Diagram 3. Peningkatan Hasil Ketuntasan Belajar Klasikal Siklus I dan Siklus II}

Ketuntasan belajar klasikal pada siklus 1 sebesar 25,71\% karena ada 9 siswa yang mendapat nilai sesuai standar $\mathrm{kkm} \leq$ 80. Pada siklus 2 sebanyak 27 siswa yang mendapat nilai sesuai standar kkm $\leq 80$ dengan ketuntasan belajar klasikal $80 \%$. Dapat diseimpulkan bahwa ketuntasan belajar klasikal dari siklus 1 ke siklus 2 meningkat sebesar $54,29 \%$ dengan ketuntasan belajar klasikal telah berhasil mencapai $80 \%$. Demikian hasil deksripsi penilaian keseluruhan yang sudah dilakukan membuktikan bahwa pembelajaran menulis naskah drama dengan menggunakan media line webtoon dapat meningkatkan hasil belajar siswa.

\section{Pembahasan}

Berdasarkan hasil pelaksanaan pembelajaran yang telah dilakukan selama dua siklus, terdapat data-data yang mengalami peningkatan. Pendekatan media line webtoon yang digunakan dalam menulis naskah drama dapat meningkatkan proses pembelajaran dan hasil tes belajar siswa kelas VIII-7. Sudjanadan Rivai (2002:68) menyatakan media komik dalam proses belajar mengajar dapat menciptakan minat para peserta didik, dapat mengefektifkan proses belajar mengajar, meningkatkan minat belajar dan menimbulkan minat apresiasi. Penulis memilih line webtoonsebagai media pembelajaran yang berisikomik digital dalam penelitiannya disesuaikan dengan fenomena dan perkembangan teknologi saat ini, dan dalam penggunaannya membuat siswa antusias dan tertarik untuk menulis naskah drama.

Subjek didik dalam penelitian ini berdasarkan silabus kurikulum 2013, yakni menulis naskah drama yang merupakan materi pembelajaran bahasa Indonesia siswa kelas VIII SMP/MTs semester 2. Pemilihan komik juga ditentukan oleh guru untuk menghindari dampak negatif yang ditimbulkan karena line webtoon memiliki berbagai genre komik bagi pembaca dewasa yang tidak layak dibaca oleh anakanak remaja atau siswa pada jenjang Sekolah Menengah Pertama. Penulisdalam melakukan penelitian ini memilih komik dengan judul Pak Guru Inyong karya Anggorollhank. Komik Pak Guru Inyong memiliki cerita yang ringan, terdapat pesanpesan pendidikan, nilai-nilai moral yang menarik dijadikan pembelajaran, dan tidak menimbulkan dampak buruk bagi peserta didik karena gambar dansegi cerita tidak memiliki unsur negatif.

Pelaksanaan kegiatan pembelajaran siklus 1 terlaksana sesuai dengan perencanaan walaupun terdapat gangguan yang terjadi saat proses pembelajaran dan 
berpengaruh pada hasil menulis naskah drama yang belum memuaskan. Pada pertemuan pertama siklus I terdapat gangguan kecil tetapi bisa diatasi oleh guru, yakni jaringan WiFi yang ada di sekolah tidak terkoneksi dengan baik lantaran keberadaan kelas yang berada di bawah dan pemakaian yang digunakan sebagian siswa saat mengunduh line webtoon di playstore membuat koneksi internet menjadi lambat, namun guru sudah menyiapkan kuota data internet agar pembelajaran tetap berjalan sebagimanamestinya. Pertemuan kedua siklus I konsentrasi siswa bekurang dansiswa tidak focus pada saat jam kedua yang merupakan jam pertama bahasa Indonesia karena pembelajaran sebelumnyasiswa melakukan praktik menari. Kurangnya konsentrasi siswa berpengaruh pada hasil menulis naskah drama yang belum memuaskan.

Pada siklus I hasil menulis diperoleh nilai rata-rata 70,1 dan ketuntasan belajar klasikal 25,71\%. Perolehan hasil dalam menulis naskah drama rata-rata masih rendah pada bagian dialog, alur, dan masih ada yang salah dalam menulis petunjuk teknis.Dialog yang digunakan sudah sesuai dengan tiap-tiap karakter tokoh yang berbeda dengan bahasa yang komunikatif, tetapi pilihan diksi pada dialog kurang sesuai sehingga irama lakon yang membentuk panjang pendeknya kata-kata dalam dialog kurang berpengaruh terhadap alur naskah drama. Komaidi (2011:187) berpendapat bahwa naskah drama itu mengutamakan ucapan-ucapan atau pembicaraan tokoh, dari pembicaraan para tokoh itu pembaca dapat menangkap dan mengerti seluruh ceritanya.

Alur yang digunakan mendukung jalinan ceritakarena memiliki kelengkapan eksposisi, komplikasi, klimaks dan resolusi, akan tetapi terdapat cerita yang terpotong membuat cerita menjadi kurang logis. Penulisan petunjuk teknis berbentuk petunjuk tentang setting cerita yang disam- paikan secara tidak detail, sehingga sukar dalam penafsiran naskah dan bentuk tulisan rata-rata sama dengan penulisan dialog. Pada siklus I guru sudah merata dalam membimbing dengan berkeliling kelas dan menghampiri siswa karena masih ada siswa yang kebingungan tetapi malu untuk bertanya. Kesulitan selama proses pembelajaran terjadi karena keadaan lingkungan yang dijelaskan pada observasi siklus I mempengaruhi konsentrasi siswa, sehingga pemahaman siswa dalam membuat naskah drama menentukan berhasil tidaknya proses pembelajaran yang dilaksanakan. Dari beberapa kekurangan di siklus I, dilakukan refleksi untuk siklus II, maka di siklus II merupakan perbaikan proses pembelajaran di siklus I.

Pada siklus II siswa terlihat lebih berkonsentrasi dalam menulis naskah drama, mereka sudah mendapat gambaran tentang menulis drama dan hal yang harus diperhatikan dalam menulis naskah drama.Suasanakelas menjadi nyaman karena sebelumnya pada siklus I anakanak kurang berkonsentrasi karena jam pertama melakukan pembelajaranpraktik menari sebelum bahasa Indonesia menguras tenaga mereka yang dilaksanakan pada hari jumat, namun pada siklus II pelaksanaan dilakukan hari kamis (29 Maret dan 65 April 2018) berturut-turut dikarenakan jumat sebelumnya (30 Maret 2018) adalah hari libur nasional.Pada siklus I diperoleh nilai rata-rata 70,1 sedangkan pada siklus ke II nilai rata-rata siswa meningkat menjadi 83,3. Berdasarkan hasil tersebut, maka dapat dikatakan bahwa nilai siswa sudah tuntas dan sudah mencukupi KKM sebesar 80. Kesulitan-kesulitan siswa dalam menulis naskah drama dapat teratasi dengan baik karena stuasi pembelajaran siklus II lebih terkondisi.

Hamalik (dalam Arsyad, 2006:15) mengemukakan pemakaian media pembelajaran dalam proses belajar mengajar dapat membangkitkan keinginan 
dan minat yang baru, membangkitkan motivasi dan rangsangan kegiatan belajar, dan bahkan membawa pengaruh-pengaruh psikologis terhadap siswa. Salah satu gambaran yang paling banyak dijadikan acuan sebagai landasan teori penggunaan media dalam proses belajar Dale's Cone of Experience (Kerucut Pengalaman Dale) (Arsyad, 2016:10). Berikut gambaran kerucut pengalaman Dale.

Konkret

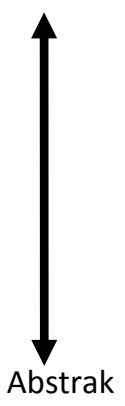

Konkret

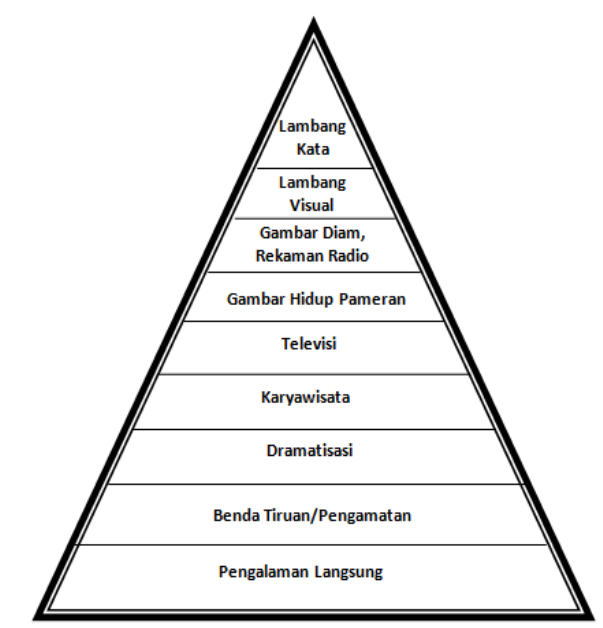

Gambar 3.Kerucut Pengalaman Edgar Dale

Pada penelitian ini media yang digunakan adalah media line webtoon berisikan beragam komik yang termasuk dalam lambang visual, yaitu gambar yang secara keseluruhan dari sesuatu yang dijelaskan ke dalam suatu bentuk yang dapat divisualisasikan (Sanaky, 2009:43). Proses pembelajaran pada penelitian ini melibatkan lambang visual, yakni media komik untuk menginspirasi siswa dalam menulis naskah drama. Media komik tingkat keabstrakan urutan kedua pada kerucut pengalaman Dale, tetapi dalam proses kreatif siswa dalam menulis naskah drama juga melibatkan pengalaman langsung, pengamatan dan dramatisasi siswa. Pengalaman langsung itu secara tidak sadar akan ditulis oleh siswa baik nyata atau dengan sentuhan imajinatif pada saat menulis naskah drama. Pada tahap pengamatan atau pengalaman tiruan siswa sudah mulai aktif dalam berpikir untuk mengembangkan penulisan naskah drama. Arsyad (2006:12) menyatakan sesungguhnya, pengalaman konkret dan pengalaman abstrak dialami silih berganti, hasil belajar dari pengalaman langsung mengubah dan memperluas jangkauan interpretasi lambang kata membantu siswa untuk memahami pengalaman yang didalamnya ia terlibat langsung.Tahap pengamatan atau pengalaman tiruan siswa

Sudjana dan Rivai (2002:68) menyatakan media komik dalam proses belajar mengajar menciptakan minat para peserta didik, mengefektifkan proses belajar mengajar, dapat meningkatkan minat belajar dan menimbulkan minat apresiasinya. Media komik dalam pembelajaran sebaiknya tidak menggunakan kata-kata kotor tetapi menggunakan kata-kata yang mengandung pesan-pesan pengetahuan gambar-gambar pelaku kekerasan diganti dengan contohcontoh perilaku bernuansa moral, adegan percintaan diganti dengan adegan yang mengarahkan rasa cinta dan kasih sayang terhadap sesama makhluk dan penciptanya.

Aktivitas pembelajaran melalui media line webtoon di kelas ditunjukkan dengan proses pelakasanaan dan hasil menulis drama pada siklus I dan siklus II. Siswa menjadi lebih antusias untuk menulis jika ada sesuatu yang bisa menginspirasi mereka, seperti komik yang ada di line webtoon. Memberikan kebebasan bagi anak dalam menentukan tema tulisan yang disukainya sesuai komik yang dibaca untuk mengembangkan kreativitas tulisannya tetapi guru harus memberikan batasanbatasan komik yang akan dibaca siswa. Siswa begitu bersemangat belajar jika ada hal yang bisa menginpirasinya dan guru sebagai fasilitator mengarahkan selama proses pembelajaran berlangsung. Kelas pun menjadi bermakna apabila interaksi antara siswa dan guru berlangsung dengan baik. 


\section{PENUTUP}

Kesimpulan

Penelitian tindakan kelas yang dilakukan pada siswa kelas VIII-7 SMP Negeri 1 Kota Bengkulu dapat terlaksana dengan baik dan penelitian ini dapat mengetahui peningkatan yang terjadi pada penulisan naskah drama siswa yang dilaksanakan selama dua siklus. Peningkatan dapat diketahui dari proses pembelajaran dan hasil penulisan naskah drama menggunakan media line webtoon dari siklus 1 ke siklus 2. Dengan menggunakan media line webtoon sebagai media pembelajaran dapat menarik minat siswa dalam menulis dan guru dapat memanfaatkan media apa pun yang sesuai dengan perkembangan zaman untuk meningkatkan antusias siswa dalam pembelajaran menulis. Proses pembelajaran juga mengalami peningkatan karena motivasi belajar dan kondisi kelas yang juga mempengaruhi tingkat konsentrasi siswa menjadi lebih baik. Apresasi sastra juga terlihat ketika siswa bangga atas karya yang telah dibuat dan membuat siswa antusias untuk meningkatkan penulisan naskah drama yang lebih menarik dari sebelumnya.

\section{Saran}

Berdasarkan peneilitian yang sudah dilakukan bahwa penggunaan media dalam proses pembelajaran harus disesuaikan dengan tingkat kebermanfaatan dan batas usia peserta didik, seperti halnya media line webtoon. Media ini dapat dijadikan media pembelajaran dan meningkatkan hasil belajar siswa, tetapi tidak semua komik bisa dijadikan media pembelajaran hanya beberapa komik yang dirasa sesuai dengan jenjang tingkat sekolah atau usia peserta didik. Oleh karena itu, guru diharapkan selalu berinovasi dalam memanfaatkan media pembelajaran yang lain dalam setiap aspek keterampilan berbahasa.

\section{DAFTAR PUSTAKA}

Arsyad, Azhar. 2002. Media Pembelajaran. Jakarta:PT Raja Grafindo Persada.

Ismawati, Esti. 2013. Pengajaran Sastra. Yogyakarta: Penerbit Ombak.

Komaidi, Didik. 2011. Menulis Kreatif. Yogyakarta: Sabda Media.

Ratna, Nyoman Kutha. 2014. Peranan Karya Sastra, Seni, dan Budaya dalam Pendidikan Karakter. Yogyakarta: Pustaka Pelajar.

Sanaky, Hujair AH. 2006. Media Pembelajaran. Yogyakarta: Safira Insania Press.

Sudjana, N. dan Rivai, A. 2002. Media Pengajaran. Bandung:Penerbit CV Sinar Baru.

Sukino. 2010. Menulis Itu Mudah. Yogyakarta: Pustaka Populer LkiS.

Susetyo. 2015. Penelitian Kuantitatif dan Penelitian Tindakan Kelas. Bengkulu: Universitas Bengkulu.

Waluyanto, H, D. 2005. Komik Sebagai Media Komunikasi Visual Pembelajaran. Jurnal Pendidikan, Vol. 7. No. 1:45-55. 